\title{
Effect of Sowing and Harvesting Dates on Yield and Yield Components of Some Barley Cultivars
}

\author{
Al-Hwaidi, Nadia E. A. ${ }^{1}$, N. Kh. El-Gizawy ${ }^{1}$, A. M. Sharoba ${ }^{2}$ and S. A. S. Mehasen ${ }^{1 *}$ \\ ${ }^{1}$ Agron. Dep., Fac. of Agric., Moshtohor, Benha Univ., Egypt. \\ ${ }^{2}$ Food Sci. Dep., Fac. of Agric., Moshtohor, Benha Univ., Egypt. \\ *Corresponding author: Sadiek Abdelaziz Sadiek Mehasen, Head of Agronomy Department, Faculty of \\ Agriculture at moshtohor, Benha University, Egypt. PO Box 13736.
}

\begin{abstract}
Two field experiments were conducted at Moshtohor region, Kalubia Governorate, Egypt, during $2019 / 20$ and $2020 / 21$ seasons, to study the effect of three sowing dates $\left(1^{\text {st }}\right.$ November, $15^{\text {th }}$ November, $1^{\text {st }}$ December) and three harvesting dates (Harvesting at 150 DAS after sowing , Harvesting at 165 DAS after sowing, Harvesting at 180 DAS after sowing) on yield and yield components of two barley cultivars (Giza 2000 and Bhoth 244). The experimental design was randomized complete block design using split split-plots arrangement with three replications. Sowing dates was arranged in the main plots and barley cultivars was arranged at random in the sub plots, while harvesting dates were arranged randomly by in the sub sub-plots. The main results were as follows: Sowing at $1^{\text {st }}$ or $15^{\text {th }}$ of November gave the highest values of all studied traits except spike length and harvest index in first season and plant height in second season. Meanwhile, Bhoth 244 cultivar gave the highest values of spike length, No. spikelets spike ${ }^{-1}$, spike weight, No. grains spike ${ }^{-1}$, grain yield fed ${ }^{-1}$ and straw yield fed ${ }^{1}$, whereas Giza 2000 cultivar gave the highest values of plant height, 1000-kernel weight and harvest index in the first and second seasons. Harvesting at 150 DAS increased significantly spike weight, No. grains spike ${ }^{-1}, 1000-$ kernel weight and straw yield fed $^{-1}$ compared with the other harvesting dates, while spike length, No. spikelets spike $^{-1}$, grain yield fed ${ }^{-1}$ and harvest index increased significantly by harvesting at 180 DAS in both seasons. Plant height, spike weight, No. grains spike ${ }^{-1}$, grain yield fed ${ }^{-1}$ and straw yield fed ${ }^{-1}$ were affected by the interaction between sowing dates and barley cultivars in both seasons except plant height in the second season and No. grains spike $^{-1}$ in the first season. Moreover, plant height, spike length, spike weight, No. grains spike ${ }^{-1}, 1000-$ kernel $^{2}$ weight, grain yield fed ${ }^{-1}$, straw yield fed ${ }^{-1}$ and harvest index were affected by the interaction between sowing dates and harvesting dates in both seasons except plant height, spike length, straw yield fed ${ }^{-1}$ and harvest index in the first season. While, plant height, No. spikelets spike ${ }^{-1}$, spike weight, No. grains spike ${ }^{-1}, 1000$-kernel weight, grain yield $\mathrm{fed}^{-1}$, straw yield $\mathrm{fed}^{-1}$ and harvest index were affected by the interaction between barley cultivars and harvesting dates in both seasons except plant height, No. spikelets spike ${ }^{-1}$, grain yield fed ${ }^{-1}$, straw yield fed ${ }^{-1}$ and harvest index in the first season. Regarding the interaction effect, among sowing dates, barley cultivars and harvesting dates were significant differences of plant height, spike weight, No. grains spike ${ }^{-1}, 1000$-kernel weight, grain yield fed ${ }^{-1}$, straw yield fed ${ }^{-1}$ and harvest index in both seasons except straw yield fed ${ }^{-1}$ and harvest index in the first season. It can be concluded that sowing Bhoth 244 cultivar in $1^{\text {st }}$ or $15^{\text {th }}$ November and harvesting at 180 DAS produced the height yield productivity under the conditions of this experiment.
\end{abstract}

Key Words: Sowing dates, Barley cultivars, Harvesting dates, Yield and yield components.

\section{Introduction}

Barley (Hordeum vulgare L.) is an important cereal crop not only in Egypt but also all over the world. Among cereals, it ranks fourth in terms of cereal acreage and total production after wheat, maize and rice (FAO, 2021). Barley is a winter cereal crop in Egypt and usually used as human food and animal feed. Barley is production throughout the temperate, because good adaptability to wide range of climate. It responds well to date of sowing, varieties and harvesting dates which varies from country to country. The recent climate change is characterized by decreasing precipitation and increasing temperature, resulting in greater aridity. In this concern, sowing date differ in barley yield and yield components as reported by Chaudhary et al (2017), Pal et al (2018), Reddy et al (2018), Lee and Kim (2019), Amarjeet et al (2020) and Moustafa et al (2021).
Effect of cultivars on barley yield and yield components were studied by several researches Kokare et al (2014), Chaudhary et al (2017), Pal et al (2018), Dari et al (2019), Singh et al (2020) and Moustafa et al (2021).

Consequently, many researchers reported that harvesting dates is the most limiting factor to increase barley yield and yield components among those are Kharub et al (2007), Pal and Kumar (2009), Sharma (2009), Jain and Nagar (2010), Kaur et al (2013) and Nadimpoor and Mojaddam (2015).

The objective of this study was to investigate the suitable agricultural management practices such as planting and harvesting dates for two barley cultivars grown on a clay soil in Kalubia Governorate. 


\section{Materials and Methods}

Two field experiments were carried out at Moshtohor region, Kalubia Governorate, Egypt, in $2019 / 2020$ and 2020/2021seasons, to study the effect of three sowing dates $\left(1^{\text {st }}\right.$ November, $15^{\text {th }}$ November and $1^{\text {st }}$ December) and three harvesting dates (Harvesting at 150 (DAS), Harvesting at 165 (DAS) and Harvesting at 180 (DAS) on yield and yield components of two barley cultivars (Giza 2000 and Bhoth 244). The soil was clay in texture with a $\mathrm{PH}$ value of 7.94 and 7.96 and an organic matter content of 17.5 and $17.2 \mathrm{mg} \mathrm{kg}^{-1}$ and total $\mathrm{N}$ of 0.15 and $0.13 \%$ during the first and second seasons, respectively. Eighteen

Every experiment included eighteen treatments which were the combination of three sowing dates, two barley cultivars and three harvesting dates. The experimental design was a Randomized Complete Blok Design using a split splitplot with three replications. The three sowing dates were arranged at random in the main plots, the sub plots were assigned random by to the two barley cultivars randomly and the three harvesting dates were arranged random by in the sub sub-plots. The sub subplot area was $10.5 \mathrm{~m}^{2}(3 \times 3.5 \mathrm{~m})$.

During land preparation, calcium super phosphate (12.5\%), at a rate of $25 \mathrm{~kg} \mathrm{P}_{2} \mathrm{O}_{5}$ fed $^{-1}$ was applied. Barley kernels were hand drilled in rows and the experimental unit area was $10.5 \mathrm{~m}^{2}$ consisting 15 rows each of $3.5 \mathrm{~m}$ in length and $20 \mathrm{~cm}$ apart. Sowing date was on Nov. $1^{\text {st }}, 15^{\text {th }}$ and $1^{\text {st }}$ Dec. in both seasons. The preceding summer crop was corn in both seasons. Nitrogen fertilizer at a rate of $70 \mathrm{~kg} \mathrm{~N}$ fed $^{-1}$ was split into two equal doses applied before the first and the second irrigations in the both seasons. The used $\mathrm{N}$ carrier was urea $(46.5 \% \mathrm{~N})$. Other agricultural practices were done as recommended in similar region.

Random samples of 10 guarded plants were taken from sub sub-plots at harvesting time to determine the following characters: plant height $(\mathrm{cm})$, spike length $(\mathrm{cm})$, No. spikelets spike ${ }^{-1}$, spike weight (g) and No. grains spike ${ }^{-1}$. For determining 1000-grain weight $(\mathrm{g})$ a sample of one square meter from each sub sub-plot was taken. Grain and straw yields $\left(\mathrm{kg} \mathrm{fed}^{-1}\right)$ were estimated on whole sub sub-plot basis. Harvest index: grain yield $\mathrm{kg} \mathrm{fed}^{-1}$ divided by Biological yield $\mathrm{kg} \mathrm{fed}^{-1}$ x 100 .

Analysis of variance was done for the data of each season separately according to Snedecor and Cochran (1980). Treatment means were compared using least significant difference test at 0.05 level of significance, using the MSTAT-C Statistical Software package (Michigan State University, 1983)

\section{Results and Discussion}

\section{-Effect of sowing dates:}

Data in Table 1 illustrated the results of the influence of sowing dates on plant height, spike length, No. spikelets spike ${ }^{-1}$, spike weight, No. grains spike $^{-1}$, 1000-kernel weight, grain yield fed $^{-1}$, straw yield fed $^{-1}$ and harvest index in two growing seasons. Plant height, spike length, No. grains spike ${ }^{-1}$ and straw yield fed ${ }^{-1}$ were significantly in $1^{\text {st }}$ Nov sown over that of $15^{\text {th }}$ Nov and $1^{\text {st }}$ Dec sown barley in both seasons except plant height in the second season and spike length in the first season. While, sowing date at midNov. produced significantly highest values for spike weight (3.66 and $3.64 \mathrm{~g}$ ), 1000-kernel weight (42.91 and $42.53 \mathrm{~g}$ ), grain yield fed $^{-1}(2370$ and $2373 \mathrm{~kg})$ and harvest index (29.10 and 31.24\%) in the first and second seasons, respectively. Lastly, No. spikelets spike ${ }^{-1}$ was significantly in $1^{\text {st }}$ Dec. sown over that of $1^{\text {st }}$ Nov. in the first season and sown over that of $1^{\text {st }}$ and $15^{\text {th }}$ Nov. in the second season. That might be due to that late sowing decreased the effective rate of grain filling, shortened the effective duration of grain filling and plant growth rate during grain filling was slower because of low daily incident radiation and radiation use efficiency. Generally, sowing date first or mid Nov. were significantly better than first Dec. date. Sowing date first-Nov. furnished suitable environmental resources i.e climatic and edaphic factors to barley kernels to well germination and seedling establishment. These results trend to agree with those obtained by Chaudhary et al (2017), Pal et al (2018), Reddy et al (2018), Lee and Kim (2019), Amarjeet et al (2020) and Moustafa et al (2021).

Table 1. Yield and its components of barley as affected by sowing dates in 2019/2020 and 2020/21 seasons

\begin{tabular}{|c|c|c|c|c|c|c|c|c|}
\hline \multirow[b]{2}{*}{ Characters } & \multicolumn{3}{|c|}{$2019 / 20$ season } & \multirow{2}{*}{$\begin{array}{c}\text { LSD } \\
\text { at } \\
\mathbf{5 \%}\end{array}$} & \multicolumn{3}{|c|}{$2020 / 21$ season } & \multirow{2}{*}{$\begin{array}{c}\text { LSD } \\
\text { at } \\
\mathbf{5 \%}\end{array}$} \\
\hline & $\begin{array}{c}1^{\text {st }} \\
\text { Nov. }\end{array}$ & $\begin{array}{l}15^{\text {th }} \\
\text { Nov. }\end{array}$ & $\begin{array}{c}1^{\text {st }} \\
\text { Dec. }\end{array}$ & & $\begin{array}{c}1^{\text {st }} \\
\text { Nov. }\end{array}$ & $\begin{array}{l}15^{\text {th }} \\
\text { Nov. }\end{array}$ & $\begin{array}{c}1^{\text {st }} \\
\text { Dec. }\end{array}$ & \\
\hline Plant height (cm) & 125.1 & 118.3 & 117.2 & 5.1 & 100.0 & 98.9 & 102.2 & $\mathbf{N S}$ \\
\hline Spike length (cm) & 9.00 & 8.88 & 8.55 & NS & 9.16 & 8.72 & 8.44 & 0.40 \\
\hline No. spikelets spike ${ }^{-1}$ & 20.16 & 20.77 & 21.44 & 0.90 & 20.22 & 20.38 & 21.55 & 0.73 \\
\hline Spike weight (g) & 3.19 & 3.66 & 3.32 & 0.08 & 3.27 & 3.64 & 3.33 & 0.11 \\
\hline No. kernels spike ${ }^{-1}$ & 65.55 & 65.33 & 60.44 & 3.7 & 66.77 & 62.33 & 60.38 & 2.12 \\
\hline 1000-kernel weight (g) & 41.71 & 42.91 & 41.58 & 0.79 & 41.26 & 42.53 & 41.41 & 0.32 \\
\hline Grain yield $\left(\mathrm{kg} \mathrm{fed}^{-1}\right)$ & 2211 & 2370 & 2128 & 15 & 2200 & 2373 & 2123 & 22 \\
\hline Straw yield $\left(\mathrm{kg} \mathrm{fed}^{-1}\right)$ & 6205 & 5849 & 5509 & 165 & 6042 & 5321 & 5366 & 62 \\
\hline Harvest index & 27.32 & 29.10 & 28.09 & NS & 27.34 & 31.24 & 28.69 & 0.66 \\
\hline
\end{tabular}

NS=No significance 


\section{-Varietal differences:}

The results reported in Table 2 indicate clearly that, there were significant differences between barley cultivars in all studied traits in the first and second seasons except harvest index in the first season. Bhoth 244 cultivar gave the highest values and increased significantly spike length (10.07 and 9.88 $\mathrm{cm})$, No. spikelets spike ${ }^{-1}$ (23.40 and 23.14 spikelet), spike weight (3.60 and $3.58 \mathrm{~g}$ ), No. kernels spike ${ }^{-1}$ (66.22 and $64.48 \mathrm{kernel})$, grain yield $\mathrm{fed}^{-1}$ (2298 and $2299 \mathrm{~kg}$ ) and straw yield $\mathrm{fed}^{-1}(6204$ and $5925 \mathrm{~kg})$ in the first and second seasons, respectively. Whereas, Giza 2000 cultivar gave the highest values and increased significantly plant height (124.0 and 104.2 $\mathrm{cm}$ ), 1000-kernel weight (44.60 and $44.14 \mathrm{~g})$ and harvest index (28.53 and 29.87\%) in the first and second seasons, respectively. It could be concluded that varietal differences between barley cultivars may be due to genetical make up. The superiority of Bhoth 244 cultivar in grain yield fed $^{-1}$ over Giza 2000 cultivar might be due to the increase in yield components, namely, spike length, No. spikelets spike $^{-1}$, spike weight and No. grains spike ${ }^{-1}$. The results obtained by Kokare et al (2014), Chaudhary et al (2017), Pal et al (2018), Dari et al (2019), Singh et al (2020) and Moustafa et al (2021) indicated marked differences among barley varieties in yield and yield components.

Table 2. Yield and its components of barley as affected by cultivars 2019/20 and 2020/21 seasons

\begin{tabular}{|c|c|c|c|c|c|c|}
\hline \multirow[b]{2}{*}{ Characters } & \multicolumn{2}{|c|}{ 2019/20 season } & \multirow{2}{*}{$\begin{array}{c}\text { LSD } \\
\text { at } \\
\mathbf{5 \%}\end{array}$} & \multicolumn{2}{|c|}{ 2020/21 season } & \multirow{2}{*}{$\begin{array}{c}\text { LSD } \\
\text { at } \\
5 \%\end{array}$} \\
\hline & $\begin{array}{l}\text { Giza } \\
2000\end{array}$ & $\begin{array}{c}\text { Bhoth } \\
244\end{array}$ & & Giza 2000 & $\begin{array}{c}\text { Bhoth } \\
244\end{array}$ & \\
\hline Plant height $(\mathrm{cm})$ & 124.0 & 116.3 & 3.3 & 104.2 & 96.6 & 3.4 \\
\hline Spike length (cm) & 7.55 & 10.07 & 0.17 & 7.66 & 9.88 & 0.46 \\
\hline No. spikelets spike ${ }^{-1}$ & 18.18 & 23.40 & 0.81 & 18.29 & 23.14 & 0.66 \\
\hline Spike weight (g) & 3.18 & 3.60 & 0.14 & 3.24 & 3.58 & 0.10 \\
\hline No. kernels spike ${ }^{-1}$ & 61.33 & 66.22 & 2.28 & 61.85 & 64.48 & 1.69 \\
\hline 1000-kernel weight (g) & 44.60 & 39.53 & 0.31 & 44.14 & 39.33 & 0.50 \\
\hline Grain yield $\left(\mathrm{kg} \mathrm{fed}^{-1}\right)$ & 2174 & 2298 & 13 & 2165 & 2299 & 14 \\
\hline Straw yield $\left(\mathrm{kg} \mathrm{fed}^{-1}\right)$ & 5505 & 6204 & 147 & 5228 & 5925 & 96 \\
\hline Harvest index & 28.53 & 27.81 & NS & 29.87 & 28.32 & 0.89 \\
\hline
\end{tabular}

NS=No significance

\section{-Effect of harvesting dates:}

Results in Table 3 indicate that grain yield and its components of barley were affected by different harvesting dates. Harvesting at 150 DAS increased significantly spike weight, No. grains spike ${ }^{-1}, 1000-$ kernel weight and straw yield fed ${ }^{-1}$ compared with the other harvesting dates, while spike length, No. spikelets spike ${ }^{-1}$, grain yield fed $^{-1}$ and harvest index increased significantly by harvesting at 180 DAS in both seasons. Such results may be due to the proper crop stand and also the production of individual plant through balancing the plant to plant competition and facilitating the conversion of light energy to harvest yield of crop. Similar results were reported by Kharub et al (2007), Pal and Kumar (2009), Sharma (2009), Jain and Nagar (2010), Kaur et al (2013) and Nadimpoor and Mojaddam (2015).

Table 3. Yield and its components of barley as affected by harvesting dates (days after sowing, DAS) in 2019/20 and 2020/21 seasons

\begin{tabular}{|c|c|c|c|c|c|c|c|c|}
\hline \multirow[b]{2}{*}{ Characters } & \multicolumn{3}{|c|}{ 2019/20 season } & \multirow{2}{*}{$\begin{array}{c}\text { LSD } \\
\text { at } \\
\mathbf{5 \%} \\
\end{array}$} & \multicolumn{3}{|c|}{ 2020/21 season } & \multirow{2}{*}{$\begin{array}{c}\text { LSD } \\
\text { at } \\
\mathbf{5 \%} \\
\end{array}$} \\
\hline & $\begin{array}{c}150 \\
\text { DAS }\end{array}$ & $\begin{array}{c}165 \\
\text { DAS }\end{array}$ & $\begin{array}{c}180 \\
\text { DAS }\end{array}$ & & $\begin{array}{c}150 \\
\text { DAS }\end{array}$ & $\begin{array}{c}165 \\
\text { DAS }\end{array}$ & $\begin{array}{c}180 \\
\text { DAS }\end{array}$ & \\
\hline Plant height (cm) & 121.1 & 119.9 & 119.5 & NS & 101.4 & 101.2 & 98.5 & NS \\
\hline Spike length (cm) & 8.38 & 8.83 & 9.22 & 0.46 & 8.44 & 8.72 & 9.16 & 0.40 \\
\hline No. spikelets spike-1 & 20.33 & 20.16 & 21.44 & 0.56 & 20.33 & 20.61 & 21.22 & 0.59 \\
\hline Spike weight (g) & 3.71 & 3.36 & 3.10 & 0.13 & 3.71 & 3.34 & 3.19 & 0.09 \\
\hline No. kernels spike ${ }^{-1}$ & 65.72 & 63.05 & 62.55 & 1.57 & 65.16 & 61.61 & 62.72 & 2.16 \\
\hline 1000-kernel weight (g) & 44.47 & 41.99 & 39.75 & 0.27 & 44.27 & 41.57 & 39.36 & 0.27 \\
\hline Grain yield (kg fed ${ }^{-1}$ ) & 2074 & 2311 & 2324 & 11 & 2078 & 2308 & 2309 & 12 \\
\hline Straw yield (kg fed ${ }^{-1}$ ) & 6704 & 5677 & 5181 & 232 & 6414 & 5561 & 4754 & 96 \\
\hline Harvest index & 24.69 & 28.65 & 31.17 & 1.95 & 25.08 & 29.42 & 32.77 & 0.75 \\
\hline
\end{tabular}

NS=No significance

- Effect of the interactions:

The significant interactions among sowing dates, barley cultivars and harvesting dates on the studied traits are shown in Tables (4A, 4B, 4C and 5)

The combination of sowing dates with barley cultivars indicated that the highest values were obtained by sown in $1^{\text {st }}$ Nov. with Giza 2000 and Bhoth 244 cultivars for plant height $(134.6 \mathrm{~cm})$ and No. kernels spike ${ }^{-1}(68.11$ kernel) in the first and second seasons, respectively and the highest values of straw yield $\mathrm{fed}^{-1}(6421$ and $6250 \mathrm{~kg}$ ) obtained by sown in $1^{\text {st }}$ Nov. with Bhoth 244 cultivar in the first and 
second seasons, respectively. Whereas Bhoth 244 cultivar at sown in $15^{\text {th }}$ Nov. gave the heaviest values for spike weight (4.12 and $4.01 \mathrm{~g}$ ) and grain yield fed ${ }^{-}$ ${ }^{1}$ (2445 and $2447 \mathrm{~kg}$ ) in the first and second seasons, respectively (Table 4A). On the other hand, the lowest values of plant height was obtained by sown in $1^{\text {st }}$ Nov. Bhoth 244 cultivar in the first season and spike weight, No. kernels spike ${ }^{-1}$, grain yield fed ${ }^{-1}$ and straw yield fed ${ }^{-1}$ were obtained by sown in $1^{\text {st }}$ Dec. with Giza 2000 cultivar in both seasons.

Table 4A. Effect of the interaction between sowing dates and barley cultivars on yield and yield components in 2019/20 (First) and 2020/21 (Second) seasons

\begin{tabular}{|c|c|c|c|c|c|c|c|c|}
\hline \multirow[b]{2}{*}{ Characters } & \multirow{2}{*}{$\begin{array}{c}\text { Sowing dates } \\
\text { cultivar }\end{array}$} & \multicolumn{2}{|c|}{$1^{\text {st }}$ November } & \multicolumn{2}{|c|}{$15^{\text {th }}$ November } & \multicolumn{2}{|c|}{$1^{\text {st }}$ December } & \multirow{2}{*}{$\begin{array}{r}\text { LSD } \\
\text { at } 5 \%\end{array}$} \\
\hline & & $\begin{array}{c}G \\
2000 \\
\end{array}$ & B 244 & G 2000 & B 244 & G 2000 & В 244 & \\
\hline \multirow{4}{*}{$\begin{array}{l}\text { Plant height } \\
\text { (cm) } \\
\text { Spike weight }(\mathrm{g})\end{array}$} & First & 134.6 & 115.6 & 119.9 & 116.7 & 117.7 & 116.7 & 5.6 \\
\hline & Second & 104.0 & 96.0 & 101.9 & 95.9 & 106.7 & 97.8 & NS \\
\hline & First & 3.50 & 2.88 & 3.21 & 4.12 & 2.84 & 3.80 & 0.25 \\
\hline & Second & 3.65 & 2.88 & 3.27 & 4.01 & 2.80 & 3.86 & 0.17 \\
\hline \multirow{2}{*}{$\begin{array}{l}\text { No. kernels } \\
\text { spike }^{-1}\end{array}$} & First & 63.88 & 67.22 & 62.66 & 68.00 & 57.44 & 63.44 & NS \\
\hline & Second & 65.44 & 68.11 & 63.11 & 61.55 & 57.00 & 63.77 & 2.93 \\
\hline Grain yield & First & 2172 & 2250 & 2295 & 2445 & 2056 & 2200 & 23 \\
\hline$\left(\mathrm{kg} \mathrm{fed}^{-1}\right)$ & Second & 2148 & 2251 & 2299 & 2447 & 2048 & 2198 & 24 \\
\hline Straw yield & First & 5988 & 6421 & 5372 & 6327 & 5154 & 5863 & 255 \\
\hline$\left(\mathrm{kg} \mathrm{fed}^{-1}\right)$ & Second & 5835 & 6250 & 4987 & 5656 & 4863 & 5869 & 166 \\
\hline
\end{tabular}

NS=No significance

The combination of sowing dates with harvesting dates showed that the highest values of plant height $(108.3 \mathrm{~cm})$ was obtained by sown in $1^{\text {st }}$ Dec. with harvest at 150 DASin the second season, spike length $(9.66 \mathrm{~cm})$ was obtained by sown in $1^{\text {st }}$ Nov. with harvest at 180 DAS in the second season, spike weight (4.01 and $4.00 \mathrm{~g}$ ) was obtained by sown in $15^{\text {th }}$ Nov. with harvest at 165 DAS in the first and second seasons, respectively, No. kernels spike ${ }^{-1}$ (69.33 and 69.33 kernel) and 1000-kernel weight ( 45.08 and $44.65 \mathrm{~g}$ ) were obtained by sown in $15^{\text {th }}$ Nov. with harvest at 150 DAS in the first and second seasons, respectively, grain yield fed ${ }^{-1}$ (2471 and 2474 $\mathrm{kg}$ ) in the first and second seasons, respectively were obtained by sown in $15^{\text {th }}$ Nov. with harvest at 180 DAS, straw yield fed ${ }^{-1}(6796 \mathrm{~kg})$ obtained by sown in $1^{\text {st }}$ Nov. with harvest at 180 DAS in the second season, lastly harvest index $(35.62 \%)$ obtained by sown in $15^{\text {th }}$ Nov. with harvest at 180 DAS in the second season (Table, 4B). On the other hand, sown in $1^{\text {st }}$ Dec. with harvest at 180 DAS gave the lowest value of plant height in the second season, sown at in $1^{\text {st }}$ Dec. with harvest at 150 DAS gave the lowest value of spike length in the second season, sown in $1^{\text {st }}$ Nov. with harvest at 180 DAS gave the lowest value of spike weight in both seasons, sown in $1^{\text {st }}$ Dec. with harvest at 180 DAS gave the lowest values of No. kernels spike $^{-1}$ and 1000-kernel weight in both seasons, sown in $1^{\text {st }}$ Dec. with harvest at 150 DAS gave the lowest values of grain yield $\mathrm{fed}^{-1}$ in both seasons, moreover sown in $15^{\text {th }}$ Nov. with harvest at 180 DAS gave the lowest value of straw yield $\mathrm{fed}^{-1}$ in the second season, lastly sown at in $1^{\text {st }}$ Dec. with harvest at 150 DAS gave the lowest values of harvest index in both seasons.

Table 4B. Effect of the interaction between sowing dates and harvesting dates on yield and yield components of barley in 2019/20 (First) and 2020/21 (Second) seasons

\begin{tabular}{|c|c|c|c|c|c|c|c|c|c|c|c|}
\hline \multirow{2}{*}{ Characters } & \multirow{2}{*}{$\begin{array}{c}\begin{array}{c}\text { sowing } \\
\text { dates }\end{array} \\
\begin{array}{c}\text { Harv. } \\
\text { dates }\end{array}\end{array}$} & \multicolumn{3}{|c|}{$1^{\text {st }}$ November } & \multicolumn{3}{|c|}{$15^{\text {th }}$ November } & \multicolumn{3}{|c|}{$1^{\text {st }}$ December } & \multirow{2}{*}{$\begin{array}{l}\text { LSD } \\
\text { at } 5 \%\end{array}$} \\
\hline & & $\begin{array}{c}150 \\
\text { DAS }\end{array}$ & $\begin{array}{c}165 \\
\text { DAS }\end{array}$ & $\begin{array}{c}180 \\
\text { DAS }\end{array}$ & $\begin{array}{c}150 \\
\text { DAS }\end{array}$ & $\begin{array}{c}165 \\
\text { DAS }\end{array}$ & $\begin{array}{c}180 \\
\text { DAS }\end{array}$ & $\begin{array}{c}150 \\
\text { DAS }\end{array}$ & $\begin{array}{c}165 \\
\text { DAS }\end{array}$ & $\begin{array}{c}180 \\
\text { DAS }\end{array}$ & \\
\hline Plant height & First & 125.8 & 124.8 & 124.5 & 122.5 & 117.0 & 115.3 & 114.8 & 118.0 & 118.6 & NS \\
\hline$(\mathbf{c m})$ & Second & 95.7 & 102.8 & 101.5 & 100.2 & 95.0 & 101.5 & 108.3 & 105.8 & 92.5 & 5.8 \\
\hline Spike length & First & 8.66 & 8.33 & 9.50 & 8.16 & 9.16 & 9.33 & 8.33 & 8.50 & 8.83 & NS \\
\hline (cm) & Second & 8.83 & 9.00 & 9.66 & 8.50 & 8.66 & 9.00 & 8.00 & 8.50 & 8.83 & 0.70 \\
\hline Spike weight & First & 4.00 & 3.10 & 2.48 & 3.51 & 4.01 & 3.46 & 3.63 & 2.96 & 3.36 & 0.24 \\
\hline (g) & Second & 3.95 & 3.13 & 2.73 & 3.50 & 4.00 & 3.43 & 3.68 & 2.90 & 3.41 & 0.15 \\
\hline No. kernels & First & 63.50 & 66.83 & 66.33 & 69.33 & 61.83 & 64.83 & 64.33 & 60.50 & 56.50 & 2.72 \\
\hline spike $^{-1}$ & Second & 62.66 & 68.33 & 68.66 & 69.33 & 57.00 & 61.83 & 64.16 & 60.00 & 56.00 & 3.75 \\
\hline 1000-kernel & First & 43.91 & 42.08 & 39.15 & 45.08 & 42.83 & 40.83 & 44.41 & 41.06 & 39.26 & 0.47 \\
\hline weight (g) & Second & 43.81 & 41.65 & 38.33 & 44.65 & 42.45 & 40.50 & 44.35 & 40.63 & 39.26 & 0.47 \\
\hline Grain yield & First & 2082 & 2275 & 2276 & 2183 & 2456 & 2471 & 1958 & 2203 & 2224 & 20 \\
\hline$\left(\mathrm{kg} \mathrm{fed}^{-1}\right)$ & Second & 2095 & 2269 & 2235 & 2191 & 2455 & 2474 & 1950 & 2202 & 2218 & 21 \\
\hline Straw yield & First & 6890 & 6125 & 5599 & 6816 & 5561 & 5170 & 6405 & 5347 & 4774 & NS \\
\hline$\left(\mathrm{kg} \mathrm{fed}^{-1}\right)$ & Second & 6796 & 6050 & 5280 & 6372 & 5119 & 4473 & 6075 & 5514 & 4509 & 167 \\
\hline Harvest & First & 25.84 & 26.80 & 29.31 & 24.29 & 30.57 & 32.45 & 23.93 & 28.57 & 31.76 & NS \\
\hline index & Second & 25.09 & 27.21 & 29.72 & 25.59 & 32.52 & 35.62 & 24.56 & 28.55 & 32.95 & 1.31 \\
\hline
\end{tabular}

NS=No significance 
The data presented in Table $4 \mathrm{C}$ demonstrated that maximum values of plant height $(106.7 \mathrm{~cm})$ in the second season was obtained by sown Giza 2000 cultivar with harvested at 180 DAS, 1000-kernel weight (47.17 and $46.86 \mathrm{~g}$ ) in the first and second seasons, respectively was obtained by sown Giza 2000 cultivar with harvested at 150 DAS, while No. spikelets spike $^{-1}$ (23.33 spikelet) in the second season was obtained by sown Bhoth 244 cultivar with harvested at $180 \mathrm{DAS}$, spike weight (3.85 and $3.81 \mathrm{~g}$ ) and No. kernels spike ${ }^{-1}$ (69.77 and 68.66 kernel) in the first and second seasons, respectively were obtained by sown Bhoth 244 cultivar with harvested at 150 DAS, also straw yield $\mathrm{fed}^{-1}(6980 \mathrm{~kg})$ in the second season was obtained by sown Bhoth 244 cultivar with harvested at 150 day, whereas grain yield fed $^{-1}$ (2392 $\mathrm{kg}$ ) and harvest index (32.82\%) in the second season were obtained by sown Bhoth 244 cultivar with harvested at 180 DAS.
Regarding the interaction effect, among sowing dates, barley cultivars and harvesting dates significant differences were detected for plant height, spike weight, No. grains spike ${ }^{-1}, 1000$-kernel weight, grain yield fed $^{-1}$, straw yield fed ${ }^{-1}$ and harvest index in both seasons except straw yield fed ${ }^{-1}$ and harvest index in the first season (Table 5). Sowing at $1^{\text {st }}$ Nov. with Giza 2000 when harvested at 165 DAS gave the highest values of plant height $(140.0$ and $110.0 \mathrm{~cm})$ in the first and second season, respectively, moreover sowing at $1^{\text {st }}$ Nov. with Giza 2000 when harvested at 150 DAS gave the highest values of spike weight (4.53 and 4.60 g) in the first and second season, respectively. Sown in $1^{\text {st }}$ Dec. with Bhoth 244 cultivar under harvested at 150 DAS gave the highest values of No. kernels spike ${ }^{1}$ (74.00 and 73.66 kernal) in the first and second seasons,

Table 4C. Effect of the interaction between barley cultivars and harvesting dates on yield and yield components in 2019/20 (First) and 2020/21 (Second) seasons

\begin{tabular}{|c|c|c|c|c|c|c|c|c|}
\hline \multirow[b]{2}{*}{ Characters } & \multirow{2}{*}{$\begin{array}{c}\text { cultivars } \\
\text { Harvesting } \\
\text { dates } \\
\end{array}$} & \multicolumn{3}{|c|}{ Giza 2000} & \multicolumn{3}{|c|}{ Bhoth 244} & \multirow[b]{2}{*}{$\begin{array}{r}\text { LSD } \\
\text { at } 5 \%\end{array}$} \\
\hline & & $\begin{array}{c}150 \\
\text { DAS }\end{array}$ & $\begin{array}{c}165 \\
\text { DAS }\end{array}$ & $\begin{array}{c}180 \\
\text { DAS }\end{array}$ & $\begin{array}{c}150 \\
\text { DAS }\end{array}$ & $\begin{array}{c}165 \\
\text { DAS }\end{array}$ & $\begin{array}{c}180 \\
\text { DAS }\end{array}$ & \\
\hline Plant height & First & 124.2 & 125.6 & 122.3 & 117.8 & 114.3 & 116.7 & NS \\
\hline$(\mathbf{c m})$ & Second & 104.2 & 101.7 & 106.7 & 98.5 & 100.8 & 90.3 & 4.7 \\
\hline No. spikelets & First & 17.44 & 18.11 & 19.00 & 23.22 & 23.11 & 23.88 & NS \\
\hline spike $^{-1}$ & Second & 17.33 & 18.44 & 19.11 & 23.33 & 22.77 & 23.33 & 0.84 \\
\hline Spike weight & First & 3.57 & 3.20 & 2.77 & 3.85 & 3.52 & 3.43 & 0.19 \\
\hline (g) & Second & 3.61 & 3.17 & 2.94 & 3.81 & 3.51 & 3.44 & 0.13 \\
\hline No. kernels & First & 61.66 & 60.44 & 61.88 & 69.77 & 65.66 & 63.22 & 2.22 \\
\hline spike $^{-1}$ & Second & 61.66 & 61.11 & 62.77 & 68.66 & 62.11 & 62.66 & 3.06 \\
\hline 1000-kernel & First & 47.17 & 44.40 & 41.76 & 42.24 & 39.58 & 37.52 & 0.38 \\
\hline weight (g) & Second & 46.86 & 44.04 & 41.51 & 41.67 & 39.11 & 37.22 & 0.38 \\
\hline Grain yield & First & 2016 & 2251 & 2255 & 2133 & 2370 & 2392 & NS \\
\hline$\left(\mathrm{kg} \mathrm{fed}^{-1}\right)$ & Second & 2025 & 2244 & 2226 & 2131 & 2373 & 2392 & 17 \\
\hline Straw yield & First & 6244 & 5404 & 4866 & 7164 & 5951 & 5496 & NS \\
\hline$\left(\mathrm{kg} \mathrm{fed}^{-1}\right)$ & Second & 5849 & 5233 & 4602 & 6980 & 5889 & 4907 & 136 \\
\hline Harvest & First & 24.64 & 29.24 & 31.71 & 24.73 & 28.05 & 30.64 & NS \\
\hline index & Second & 26.77 & 30.11 & 32.72 & 23.38 & 28.74 & 32.82 & 1.07 \\
\hline
\end{tabular}

NS=No significance

respectively. While, sown in $15^{\text {th }}$ Nov. with Giza 2000 cultivar under harvested at 150 DAS gave the highest values of 1000-kernel weight (47.73 and $47.36 \mathrm{~g}$ ) in the first and second seasons, respectively. The heaviest of grain yield fed ${ }^{-1}(2520$ and $2524 \mathrm{~kg})$ in the first and second seasons, respectively produced by sowing barley kernels in $15^{\text {th }}$ Nov. with Bhoth 244 cultivar under harvested at 180 DAS treatment. The maximum value of straw yield $\mathrm{fed}^{-1}(7126 \mathrm{~kg})$ in the second season produced by sowing barley kernels in $1^{\text {st }}$ Nov. with Bhoth 244 cultivar under harvested at 150 DAS treatment. Lastly, sown in $15^{\text {th }}$ Nov. with Giza 2000 cultivar under harvested at 180 DAS gave the highest value of harvest $(36.19 \%)$ in the second season. It can be concluded that sowing Bhoth 244 cultivar in $1^{\text {st }}$ or $15^{\text {th }}$ November and harvesting at 180 DAS after sowing under the conditions of the experiment. 
Table 5. Effect of the interaction between sowing dates, barley cultivars and harvesting dates on yield and yield components in 2019/20 (F) and 2020/21 (S) seasons

\begin{tabular}{|c|c|c|c|c|c|c|c|c|c|c|c|c|c|c|c|c|}
\hline \multirow{2}{*}{$\begin{array}{c}\text { Sowing } \\
\text { dates }\end{array}$} & \multirow[b]{2}{*}{ Cult. } & \multirow[b]{2}{*}{ HA } & \multicolumn{2}{|c|}{$\begin{array}{c}\text { Plant height } \\
(\mathbf{c m})\end{array}$} & \multicolumn{2}{|c|}{$\begin{array}{c}\text { Spike } \\
\text { weight }(\mathrm{g})\end{array}$} & \multicolumn{2}{|c|}{$\begin{array}{l}\text { No. kernels } \\
\text { spike }^{-1}\end{array}$} & \multicolumn{2}{|c|}{$\begin{array}{c}\text { 1000-kernel } \\
\text { weight }(g)\end{array}$} & \multicolumn{2}{|c|}{$\begin{array}{l}\text { Grain yield } \\
\left(\mathrm{kg} \mathrm{fed}^{-1}\right)\end{array}$} & \multicolumn{2}{|c|}{$\begin{array}{l}\text { Straw yield } \\
\left(\text { kg fed }^{-1}\right)\end{array}$} & \multicolumn{2}{|c|}{$\begin{array}{c}\text { Harvest } \\
\text { index }\end{array}$} \\
\hline & & & $\mathbf{F}$ & $\mathbf{S}$ & $\mathbf{F}$ & $\mathbf{S}$ & $\mathbf{F}$ & $\mathbf{S}$ & F & $\mathbf{S}$ & F & $\mathbf{S}$ & $\mathbf{F}$ & $\mathbf{S}$ & $\mathbf{F}$ & $\mathbf{S}$ \\
\hline & & 150 & 129.7 & 102.0 & 4.53 & 4.60 & 60.00 & 59.00 & 46.50 & 45.96 & 2050 & 2083 & 6800 & 6466 & 23.01 & 27.37 \\
\hline & G2000 & 165 & 140.0 & 110.0 & 3.46 & 3.33 & 63.66 & 69.00 & 44.50 & 44.63 & 2246 & 2223 & 5853 & 5810 & 27.13 & 27.67 \\
\hline $1^{\text {st }}$ & & 180 & 134.0 & 101.7 & 2.50 & 3.03 & 68.00 & 68.33 & 41.96 & 40.00 & 2220 & 2138 & 5313 & 5228 & 29.46 & 29.02 \\
\hline \multirow[t]{5}{*}{ Nov. } & & 150 & 122.0 & 89.3 & 3.46 & 3.30 & 67.00 & 66.33 & 41.33 & 41.66 & 2115 & 2106 & 6981 & 7126 & 28.68 & 22.81 \\
\hline & B244 & 165 & 120.0 & 97.3 & 2.73 & 2.93 & 70.00 & 67.66 & 39.66 & 38.66 & 2303 & 2315 & 6396 & 6291 & 26.47 & 26.76 \\
\hline & & 180 & 115.0 & 101.3 & 2.46 & 2.43 & 64.66 & 70.33 & 36.33 & 36.66 & 2333 & 2333 & 5886 & 5333 & 29.16 & 30.43 \\
\hline & & 150 & 125.0 & 104.0 & 3.23 & 3.26 & 70.33 & 71.33 & 47.73 & 47.36 & 2056 & 2066 & 6243 & 5960 & 24.77 & 25.73 \\
\hline & G2000 & 165 & 119.0 & 93.3 & 3.56 & 3.73 & 56.33 & 56.66 & 45.13 & 44.63 & 2407 & 2408 & 5195 & 4725 & 31.68 & 33.75 \\
\hline $15^{\text {th }}$ & & 180 & 115.6 & 108.3 & 2.83 & 2.83 & 61.33 & 61.33 & 43.50 & 43.26 & 2422 & 2424 & 4677 & 4275 & 34.11 & 36.19 \\
\hline \multirow[t]{5}{*}{ Nov. } & & 150 & 120.0 & 96.3 & 3.80 & 3.73 & 68.33 & 66.00 & 42.43 & 42.03 & 2310 & 2316 & 7390 & 6784 & 23.81 & 25.45 \\
\hline & B244 & 165 & 115.0 & 96.7 & 4.46 & 4.26 & 67.33 & 56.33 & 40.53 & 40.26 & 2505 & 2503 & 5928 & 5513 & 29.46 & 31.28 \\
\hline & & 180 & 115.0 & 94.7 & 4.10 & 4.03 & 68.33 & 62.33 & 38.16 & 37.73 & 2520 & 2524 & 5663 & 4672 & 30.79 & 25.06 \\
\hline & & 150 & 118.0 & 106.7 & 2.96 & 2.96 & 54.66 & 54.66 & 47.30 & 47.26 & 1943 & 1928 & 5690 & 5121 & 26.16 & 27.22 \\
\hline & G2000 & 165 & 117.7 & 103.3 & 2.56 & 2.46 & 61.33 & 57.66 & 43.56 & 42.86 & 2101 & 2101 & 5165 & 5165 & 28.92 & 28.91 \\
\hline $1^{\text {st }}$ & & 180 & 117.3 & 103.3 & 3.00 & 2.96 & 56.33 & 58.66 & 41.26 & 41.26 & 2124 & 2116 & 4609 & 4304 & 31.54 & 32.97 \\
\hline \multirow[t]{3}{*}{ Dec. } & & 150 & 111.7 & 110.0 & 4.30 & 4.40 & 74.00 & 73.66 & 41.53 & 41.33 & 1974 & 1971 & 7121 & 7029 & 21.70 & 21.90 \\
\hline & B244 & 165 & 118.3 & 108.3 & 3.36 & 3.33 & 59.33 & 62.33 & 38.56 & 38.40 & 2304 & 2302 & 5529 & 5864 & 28.23 & 28.19 \\
\hline & & 180 & 109.7 & 75.0 & 3.73 & 3.36 & 56.33 & 55.33 & 37.26 & 37.26 & 2324 & 2320 & 4940 & 4715 & 31.97 & 32.99 \\
\hline \multicolumn{2}{|c|}{ LSD at $5 \%$} & & 9.1 & 8.2 & 0.34 & 0.22 & 3.85 & 5.31 & 0.67 & 0.66 & 28 & 29 & NS & 237 & NS & 1.85 \\
\hline
\end{tabular}

Cult. = Barley cultivars

$\mathbf{H A}=$ Harvesting at

NS=No significance

\section{References}

Amarjeet A., B. Singh, J. Kumar, M. Kumar, R. Sharma and P. Kaushik (2020). Effect of sowing date, seed rate and row spacing on productivity and profitability of barley (Hordeum vulgare) in north India. Agricultural Sciences \& Agronomy, 5:21-36.

Chaudhary A., M. Sewhag, V.S. Hooda, B. Singh and P. Kumar (2017). Effect of different dates of sowing on yield attributes, yield and quality of Barley (Hordeum vulgare L.) cultivars. Journal of Applied and Natural Science, 9 (1): 129 - 132.

Dari B., C. W. Rogers and X. Liang (2019). Plant, grain, and soil response of irrigated malt barley as affected by cultivar, phosphorus, and sulfur applications on an alkaline soil. Journal of plant nutrition, 42(9): 1061-1071.

Jain R. K. and R. P. Nagar (2010). Fodder yield and other traits of barley varieties as influenced by sowing and cutting schedules. Range management and Agroforestry symposium issue (B): 167-171.

Kaur G., A. Singh, C.S. Aulakh and J. S. Gill (2013). Variation in forage yield and quality trait of dual purpose barley under different agronomic practices. Forage Research, 39 (1): 42-44.

Kharub A.S., R.P.S. Verma and B. Sarkar (2007). Optimization of date of cutting for green fodder in dual purpose barley. DWR News, 1(1):4.

Kokare A., L. Legzdina, I. Beinarovica, C. Maliepaard, R. E. Niks and E. T. Lammerts van Bueren (2014). Performance of spring barley (Hordeum vulgare) varieties under organic and conventional conditions. Euphytica, 197:279-293.

Lee S. M. and E. J. Kim (2019). Effects of seeding dates on dry matter yield and feed values of wholecrop barley cultivated in a paddy field. Journal of Animal Science Technology, 61(5):278-284.
Michigan State University (1983). MSTAT-C: Micro- computer Statistical Program, Version 2.0. Michigan State University, East Lansing.

Moustafa E. S. A., E.E. A. El-Sobky, H. I. A. Farag, M. A. T. Yasin, A. Attia, M. O. A. Rady, M. F. Awad and E. Mansour (2021). Sowing date and genotype influence on yield and quality of dualpurpose barley in a salt-affected arid region. Agronomy, 11 (717): 1 - 14.

Nadimpoor S. and M. Mojaddam (2015). The effect of humic acid application and harvest time of forage on grain and forage yield of dual purpose barley. Online international journal availablevol, 5 (1): 231-237.

Pal D. and S. Kumar (2009). Evaluation of dual purpose barley for fodder and grain under different cutting schedules. Range Management and Agroforestry, 30:54-56.

Pal P., M. D. Reddy, G. Pandey and A. Kumar (2018). Effect of different dates of sowing on barley (Hordeum Valgare L.) varieties under limited irrigation. Journal of Pharmacognosy and Phytochemistry, 2: 88-91.

Reddy B. C., R. Singh, R. Praveena and S. A. Sohail (2018). Effect of Sowing Dates and Levels of Nitrogen on Yield Attributes, Protein Content and Economics of Barley (Hordeum vulgare L.). International Journal of Current Microbiology and Applied Sciences, 7(8): 435-440.

Sharma N.K. (2009). Evaluation of dual purpose barley varieties under irrigated situation. Range Management and Agroforestry, 30 (1): 57-58.

Singh R., M. D. Reddy, G. Pandey and A. Kumar (2020). Effect of different levels of phosphorus on performance of barley (Hordeum vulgare L.). Journal of Pharmacognosy and Phytochemistry, 9(3): 363-366.

Snedecor, G. W. and W. G. Cochran (1980). Statistical Methods, $7^{\text {th }}$ Ed., Iowa State University. Press, Ames, Iowa, USA. 
تأثير ميعاد الزباعة والحصاد على المحصول ومكوناتة لبعض أصناف الشعير

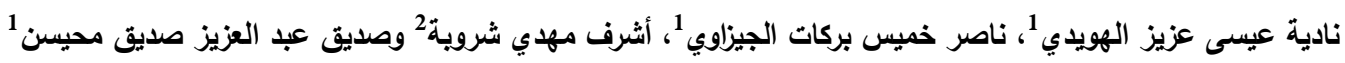

\author{
كلية الزراعة بمثتهر - جامعة بنها-ققسم المحاصيل \\ قُسم الصناعت الغذائية
}

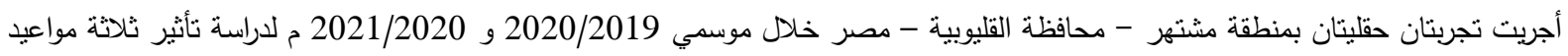

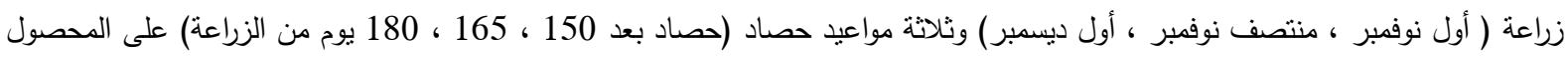

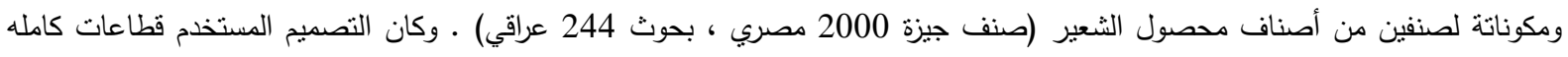

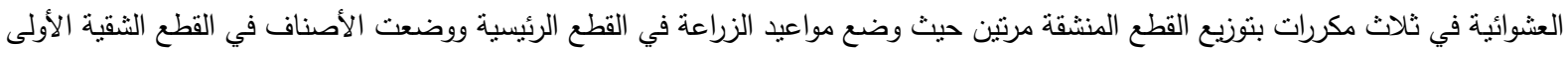

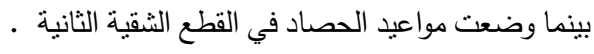
وتتلذص أهم النتائج بالآتي:.

- - مجل ميعادي الزراعة في الاول و منتصف نوفمبر أعلى القيم بفروق معنوية لمعظم الصفات المدروسة لكلا موسمي الزراعة.

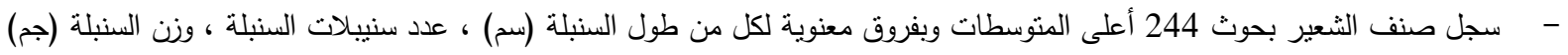

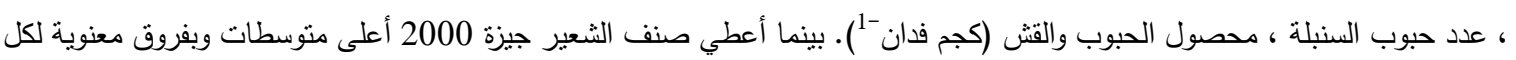
من طول النبات (سم) ، وزن الـ 1000 حبة (جم) ، النسبة المئوية لدليل الحصاد لكلا موسمي الزراعة.

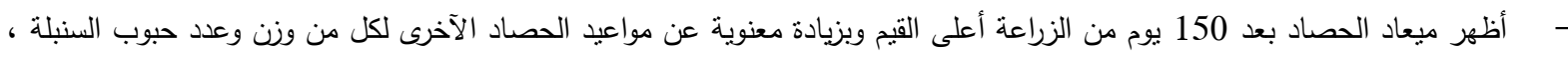

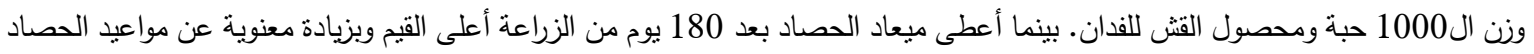

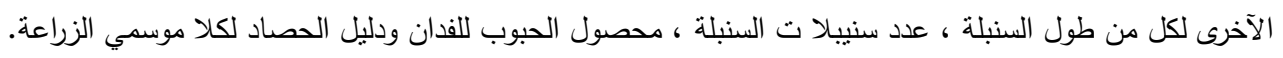

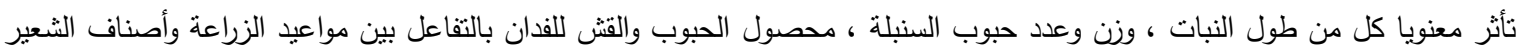

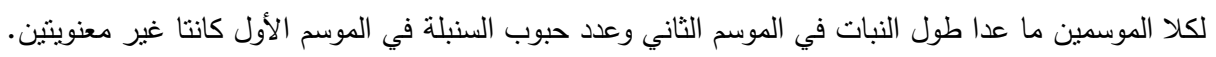

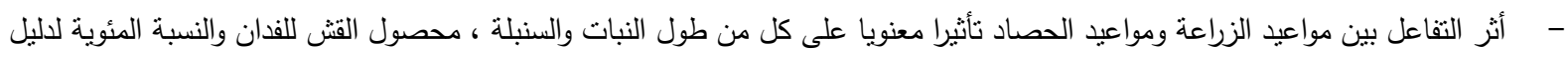

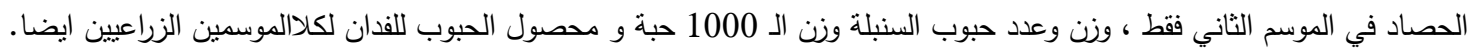

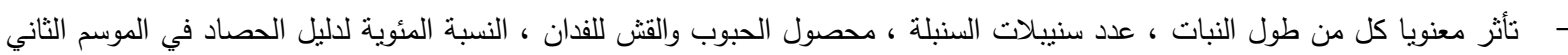

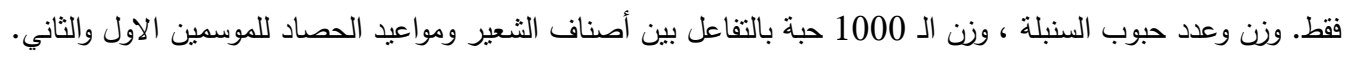

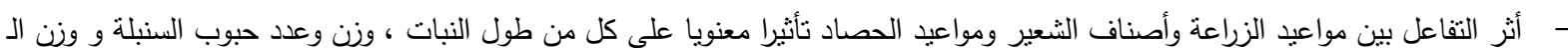

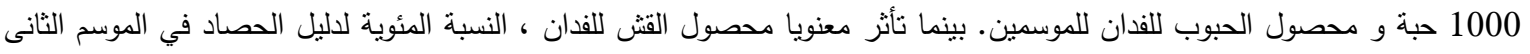
فقط. - توصي هذه الدراسة تحت ظروف تلك التجرية بزراعة صنف الثعير بحوث 244 في ميعاد الاول أو المنتصف من نوفمبر والحصاد بعد 180 يوم من الزراعة. 